\title{
Assessment of appropriate laboratory measurements to supplement the Crohn's disease activity index
}

\author{
C ANDRE, ${ }^{*}$ L DESCOS, P LANDAIS, AND J FERMANIAN
}

From the Unite de Recherche de Physiopathologie Digestive INSERM U 45, Lyon, Service d'Hépato-Gastro-Entérologie, Hôpital E Herriot, Lyon, and Groupe de Recherches de Méthodologie Informatique et Statistique en Médecine et en Santé Publique INSERM U 88, and Centre de Calcul, Hôpital de la Pitié Salpétrière, Paris, France

SUMMARY The ability of 11 laboratory parameters to reflect the degree of activity of Crohn's disease, using a clinical index as reference point was compared by means of multiple stepwise regression analysis. Activity was best defined in decreasing order by orosomucoid, sedimentation rate, $\mathrm{C}$ reactive protein, alpha-l-antitrypsin, albumin, haematocrit, IgM, circulating immune complexes, serum iron, IgG, and IgA. The haematocrit, the only laboratory measurement in the Crohn's disease activity index developed by the National Cooperative Study Group in the USA, is less discriminant than acute phase reactants. Only three parameters-namely, orosomucoid, sedimentation rate, and $\mathrm{C}$ reactive protein-have a significant weight and should be complementary to a simple clinical index.

It is generally accepted that a need exists for a numerical index of the activity of Crohn's disease at a given moment in time. Such an index would help to define the course of the disease in any individual patient, but would also be an important tool for assessing the efficacy of different therapeutic approaches, particularly in the case of multicentre trials.

Several indices have been proposed, ${ }^{12}$ but that established by the National Cooperative Study Group in the USA-CDAI-has received most attention. Although this index has been shown to be adequate in reflecting disease activity in most circumstances,${ }^{34}$ it has been criticised because of its complexity and the fact that it depends almost exclusively on clinical features-for example, well-being and pain-which are often subjective.$^{s-7}$ The only laboratory measurement used is the haematocrit.

More recently a completely objective index has been developed by Van Hees et al. ${ }^{8}$ Their evaluation of the index demonstrated convincingly that it is superior to the CDAI, and that it correlates well with a simple index of disease activity as assessed by one physician. Calculation of this index is complex and depends on measurement of various objective para-

\footnotetext{
*Address for reprint requests: C A INSERM U 45, Pav. H, Hôpital E. Herriot, 69374 Lyon Cedex 2, France.

Received for publication 28 January 1981
}

meters. It is therefore unsuitable for routine clinical use and cannot, by definition, be superior to the simple four-point clinical index.

It has, however, been suggested that the simple clinical index should be supplemented by laboratory findings, especially those measuring inflammatory activity. ${ }^{10}$ The aim of the present study was to compare the ability of 11 laboratory parameters to reflect the degree of activity of Crohn's disease, using a clinical index as reference point and making comparison by means of multiple stepwise regression analysis.

\section{Methods}

PATIENTS

The study comprised 54 patients, 19 females and 35 males, aged between 16 and 66 years, in whom the diagnosis of Crohn's disease of the ileum, colon, or both had been confirmed according to the classical clinical, radiological, endoscopic, and histological criteria. The clinical activity of the disease was graded according to a formula which did not include any laboratory parameters. Grade 1 corresponded to a state of quiescence indicated by a complete absence of signs and symptoms. Grade 2 indicated mild activity, grade 3 a moderately severe relapse, and grade 4 severe disease necessitating hospitalisation or surgery. These grades were determined by the 
presence and severity of the usual symptoms experienced by patients with Crohn's disease-that is, abdominal pain, number and consistency of stools per day, number of anti-diarrhoeal tablets taken per day, and by the presence or absence of physical signs, whether general-for example, asthenia, fever, weight loss-or more specific for the diseaseperineal lesions, abdominal mass, extra-abdominal complications. The patients were also classified according to the CDAI of the National Cooperative Group $^{1}$ and to the Dutch AI, ${ }^{8}$ using the corrections recommended for measurement of serum albumin using radial immunodiffusion.

Using the above clinical grading the disease was considered to be quiescent in 14 patients (CDAI range 5-97, AI range 45-90), mild in 14 (CDAI range 90-154, AI range 94-145), moderate in 12 (CDAI range 138-254, AI range 130-213), and severe in 14 (CDAI range 210-508, AI range 190-290).

At the same time as the clinical grade was determined blood was taken for the following laboratory tests: ESR, serum iron and haematocrit using standard techniques and serum albumin, IgA, IgG, IgM, orosomucoid, alpha-l-antitrypsin, and C-reactive protein by radial immunodiffusion using Partigen plates and the standards of Behringwerke A G (Marburg-Lahn, Germany). The titre of circulating immune complexes was also measured by Ouchterlony immunodiffusion after precipitation by polyethylene glycol. ${ }^{11}$

Stepwise multiple regression analysis was used in an attempt to assess the relationship between these 11 laboratory parameters and the clinical activity of Crohn's disease. The mathematical model used was linear and of the following form:

$$
\mathrm{yR}=\alpha+\beta_{1} \mathrm{x}_{1}+\beta_{2} \mathrm{x}_{2}+\ldots+\beta_{\mathrm{n}} \mathrm{x}_{\mathrm{n}}+\epsilon
$$

where $\epsilon$ is the error, $\beta_{\mathrm{i}}$ the regression coefficient and $\alpha$ a constant.

The activity scale was the dependent variablethat is to say, the variable to be defined. The laboratory parameters were the independent variables or in other words the defined variables. The scale of disease activity was graded from 1 to 4 , as already described. The calculations were performed at the Centre de Calcul, Hôpital Universitaire de la Pitié Salpétrière (Pr Gremy) Paris.

\section{Results}

Table 1 shows the mean and standard error of each of the 11 laboratory parameters. A correlation matrix showed no important intercorrelation between the different parameters ( $r$ was always inferior to $0 \cdot 65$ ).

The results of the stepwise regression analysis appear in Table 2, where the dependent variable was the clinical scale graded from 1 to 4 according to the clinical activity of the disease. The computation was stopped at the 10th step when the F test was insufficient to proceed further. The $F$ value was significant $(P<0.01)$ for only three parametersnamely, orosomucoid, sedimentation rate, and $\mathrm{C}$ reactive protein. The increment of the square of the multiple regression coefficient was respectively $0.593,0.050$, and 0.046 . The equation of the multiple regression analysis for these variable was

$$
y R=0.9317+0.0062 x_{5}+0.0006 x_{6}+0.0200 x_{8}
$$

where $\mathrm{x}_{5}$ is the orosomucoid, $\mathrm{x}_{6}$ the $\mathrm{C}$ reactive protein and $x_{8}$ the sedimentation rate. The standard deviation of the regression coefficient were respectively $0 \cdot 0021$, $0.0002,0.0067$. To appreciate and compare the relative contributions of the three parameters all the vari-

\begin{tabular}{|c|c|c|c|c|c|c|c|c|}
\hline \multirow[t]{3}{*}{ Variables } & \multicolumn{8}{|c|}{ Disease activity } \\
\hline & \multicolumn{2}{|c|}{ Grade 1} & \multicolumn{2}{|c|}{ Grade 2} & \multicolumn{2}{|c|}{ Grade 3} & \multicolumn{2}{|c|}{ Grade 4} \\
\hline & Mean & $\begin{array}{l}\text { Standard } \\
\text { error }\end{array}$ & Mean & $\begin{array}{l}\text { Standard } \\
\text { error }\end{array}$ & Mean & $\begin{array}{l}\text { Standard } \\
\text { error }\end{array}$ & Mean & $\begin{array}{l}\text { Standard } \\
\text { error }\end{array}$ \\
\hline$x_{1}$ Immunoglobulin A $(2 \cdot 10 \mathrm{~g} / 1)^{*}$ & $2 \cdot 51$ & $0 \cdot 89$ & $2 \cdot 39$ & $1 \cdot 10$ & $2 \cdot 81$ & 1.90 & $3 \cdot 23$ & 1.55 \\
\hline $\mathrm{x}_{2}$ Immunoglobulin $\mathrm{M}(1.40 \mathrm{~g} / \mathrm{l})^{*}$ & $1 \cdot 36$ & 0.64 & $1 \cdot 56$ & $0 \cdot 82$ & $1 \cdot 54$ & 0.85 & $1 \cdot 38$ & 0.61 \\
\hline $\mathrm{x}_{3}$ Immunoglobulin $\mathrm{G}(12.50 \mathrm{~g} / 1)^{*}$ & 11.95 & $2 \cdot 33$ & $12 \cdot 30$ & $4 \cdot 07$ & $13 \cdot 31$ & $5 \cdot 23$ & $13 \cdot 81$ & $4 \cdot 41$ \\
\hline $\mathrm{x}_{4}$ Alpha-l-antitrypsin $(2.90 \mathrm{~g} / 1)^{*}$ & 3.09 & $1 \cdot 14$ & 3.44 & 0.65 & $4 \cdot 45$ & 1.06 & $4 \cdot 74$ & 0.78 \\
\hline$x_{5}$ Orosomucoid $(0.90 \mathrm{~g} / \mathrm{l})^{*}$ & $0 \cdot 70$ & $0 \cdot 15$ & 0.97 & 0.43 & 1.47 & $0 \cdot 55$ & $2 \cdot 07$ & 0.52 \\
\hline$x_{6}$ C reactive protein $(<1 \mathrm{mg} / \mathrm{dl})^{*}$ & $0 \cdot 08$ & $0 \cdot 24$ & $1 \cdot 36$ & $2 \cdot 19$ & $3 \cdot 30$ & $2 \cdot 43$ & $8 \cdot 88$ & $6 \cdot 52$ \\
\hline$x_{7}$ Albumin $(44 \cdot 00 \mathrm{~g} / 1)^{*}$ & $42 \cdot 93$ & $3 \cdot 00$ & $39 \cdot 54$ & $4 \cdot 86$ & $32 \cdot 65$ & $5 \cdot 50$ & $30 \cdot 87$ & $8 \cdot 08$ \\
\hline$x_{8}$ Sedimentation rate $(<20 \mathrm{~mm} / \mathrm{l} \mathrm{h})^{*}$ & $12 \cdot 57$ & $9 \cdot 61$ & $12 \cdot 50$ & $5 \cdot 10$ & $40 \cdot 75$ & $13 \cdot 50$ & $39 \cdot 64$ & $16 \cdot 55$ \\
\hline$x_{9}$ Serum iron $(19 \mathrm{micromol} / \mathrm{l})^{*}$ & $18 \cdot 96$ & 5.97 & $16 \cdot 81$ & $6 \cdot 71$ & $11 \cdot 07$ & $4 \cdot 11$ & $8 \cdot 15$ & $3 \cdot 32$ \\
\hline $\begin{array}{c}x_{10} \text { Antigen-antibody complex } \\
(\text { titre reciprocal: } 0)^{*}\end{array}$ & $0 \cdot 29$ & $0 \cdot 73$ & $0 \cdot 50$ & 0.76 & $0 \cdot 17$ & 0.39 & 0.93 & $1 \cdot 14$ \\
\hline \multicolumn{9}{|l|}{$x_{11}$ Haematocrit } \\
\hline 42 units, women & $38 \cdot 84$ & $2 \cdot 04$ & 43.06 & $3 \cdot 07$ & $38 \cdot 15$ & $3 \cdot 42$ & $35 \cdot 63$ & $1 \cdot 52$ \\
\hline 47 units, men* & $44 \cdot 72$ & $2 \cdot 60$ & $44 \cdot 54$ & $3 \cdot 72$ & $40 \cdot 90$ & $2 \cdot 65$ & $36 \cdot 78$ & $5 \cdot 70$ \\
\hline
\end{tabular}

Table 1 Mean and standard error of 11 laboratory parameters measured in 54 patients

*Normal values 
Table 2 Stepwise multiple regression analysis with clinical scale as dependent variable

\begin{tabular}{|c|c|c|c|c|c|}
\hline Steps (no.) & Variables & $M R C^{*}(R)$ & Square of $M R C\left(R^{2}\right)$ & Increment of $R^{2}$ & Fvalue \\
\hline 1 & Orosomucoid ( $\mathbf{x}_{\mathbf{s}}$ ) & $0 \cdot 770$ & $0 \cdot 593$ & $0 \cdot 593$ & $75 \cdot 76^{+}$ \\
\hline 2 & Sedimentation rate $\left(\mathbf{x}_{\mathbf{8}}\right)$ & $0 \cdot 802$ & $0 \cdot 643$ & $0 \cdot 050$ & $7 \cdot 20+$ \\
\hline 3 & C Reactive protein $\left(x_{6}\right)$ & $0 \cdot 830$ & 0.689 & 0.046 & $7 \cdot 40+$ \\
\hline 4 & Alpha-l-antitrypsin $\left(\mathbf{x}_{4}\right)$ & $0 \cdot 840$ & $0 \cdot 706$ & $0 \cdot 017$ & $2 \cdot 89$ \\
\hline 5 & Albumin $\left(x_{7}\right)$ & 0.848 & $0 \cdot 720$ & $0 \cdot 013$ & $2 \cdot 33$ \\
\hline 6 & Haematocrit $\left(\mathrm{x}_{11}\right)$ & 0.851 & 0.725 & $0 \cdot 004$ & $0 \cdot 83$ \\
\hline 7 & Immunoglobulin $\mathbf{M}\left(\mathbf{x}_{2}\right)$ & $0 \cdot 854$ & 0.729 & $0 \cdot 004$ & 0.76 \\
\hline 8 & Antigen-antibody complex $\left(x_{10}\right)$ & $0 \cdot 858$ & 0.736 & 0.007 & 1.23 \\
\hline 9 & Serum Iron $\left(x_{q}\right)$ & 0.859 & 0.739 & $0 \cdot 002$ & $0 \cdot 42$ \\
\hline 10 & Immunoglobulin $\mathrm{G}\left(\mathrm{x}_{3}\right)$ & $0 \cdot 860$ & 0.741 & 0.001 & $0 \cdot 25$ \\
\hline
\end{tabular}

*Multiple regression coefficient.

+Significant at $1 \%$ level.

ables were normalised. The regression coefficient in the equation became respectively $0.428,0.322$, and $0 \cdot 361$. Thus the orosomucoid exerted the best correlation with the activity scale, followed by the sedimentation rate and by the $C$ reactive protein.

A similar computation was performed with the CDAI as dependent variable. The orosomucoid, the sedimentation rate, and the $\mathrm{C}$ reactive protein exerted the same qualities as in the first computation. Neither in the first computation nor in the second did the haematocrit appear significant.

\section{Discussion}

The main objection which can be raised to the CDAI is that about $40 \%$ of the index is derived from subjective criteria such as pain and well-being, while it takes no account of objective measurements of inflammation in a disease which is by definition inflammatory in nature. These difficulties have been overcome in the index developed by Van Hees et al. ${ }^{8}$ but their entirely objective index is cumbersome and its development depended on the comparison of the subjective impression of the significance of a combination of objective data with a simple clinical index. For everyday purposes, it cannot therefore be considered to be more useful than the physician's simple clinical index. The aim of the present study was different, in that we sought the laboratory parameter(s) which correlated best with the simple clinical index, and would therefore provide useful, simple, and objective corroboration of the simple index. The need for such a supplement to the latter has already been emphasised. ${ }^{10}$ Whereas the Dutch workers assessed a cumulative correlation of laboratory parameters, we have assessed each parameter individually against the simple clinical index and the CDAI.

The results obtained indicate that the activity of Crohn's disease is accurately reflected by the level of the acute phase proteins and that of all the parameters studied only orosomucoid, ESR, and C reactive protein correlated significantly with clinical status. These parameters are, of course, no more specific for Crohn's disease than the clinical index, but they are easy and cheap to measure. Because of their nonspecificity a case can be made for measuring all three, particularly as they may not behave identically-C reactive protein, for example, possibly being useful in predicting relapse. ${ }^{12}$ The superiority of these parameters over haematocrit, the only laboratory measurement included in the CDAI, seems clear. Unlike Van Hees et al. ${ }^{8}$ we did not find that, when taken alone, the serum albumin correlated well with clinical activity. A further point worthy of note is that the activity of Crohn's disease seems to be indicated equally well by a simple 15 point index as by the complex $\mathrm{CDAI}^{5}$ or by the Dutch AI, or, indeed, by our own simple classification into four subgroups, resembling Truelove's classification of ulcerative colitis. ${ }^{13}$ Of all these indices, it now seems clear that the CDAI is the least useful.

The criticism that the CDAI has received has led to the suggestion that it should be replaced by a more workable clinical index supplemented by at least one laboratory measure of inflammatory activity. ${ }^{10} \mathrm{We}$ suggest that, in view of their strong correlation with clinical disease activity, orosomucoid, ESR, and C reactive protein are the most suitable laboratory measurements to add to a practical clinical index of Crohn's disease activity.

This study was supported by grants from INSERM and La Caisse Nationale de l'Assurance Maladie des Travailleurs Salariés (CRL 79.5.459.7), from the UER Faculté de Médecine Grange-Blanche, Lyon and from the Fondation Marcel Mérieux, Lyon. We thank Dr J. Gillon for editorial help.

\section{References}

'Best WR, Becktel JM, Singleton JW, Kern F Jr. Development of a Crohn's disease activity index-National cooperative Crohn's disease study. Gastroenterology 1976; 70: $439-44$. 
${ }^{2}$ O'Donoghue DP, Dawson AM, Powell-Tuck J, Brown RL, Lennard-Jones JE. Double-blind withdrawal trial of azathioprine as maintenance treatment for Crohn's disease. Lancet 1978; 2: 955-57.

${ }^{3}$ Best WR, Becktel JM, Singleton JW. Rederived values of eight coefficients of the Crohn's disease activity index. Gastroenterology 1979; 77: 843-46.

${ }^{4}$ Teixeira M, Ferguson $\mathrm{A}$. Uses and limitations of the Crohn's disease activity index. Arq Gastroenterol S Paulo 1979; 16: 67-72.

${ }^{5}$ Harvey RF, Bradshaw JM. A simple index of Crohn's disease activity. Lancet 1980; 1: 514.

${ }^{6}$ Mee AS, Brown DJ, Jewell DP. Crohn's disease activity index-is it useful? Gut 1978; 19: 990.

${ }^{7}$ André C, Descos L, Cerf M. Comment convient-il d'apprécier l'activité de la maladie de Crohn? Gastroenterol Clin Biol 1979; 3: 785-88.

${ }^{8}$ Van Hees PAM, Van Elteren PH, Van Lier HJJ, Van Tongeren JHM. An index of inflammatory activity in patients with Crohn's disease. Gut 1980; 21: 279-86. ${ }^{9}$ André $\mathrm{C}$, Descos L, André F, Vignal J, Druguet $\mathrm{M}$. Intérêt du dosage de la protéine $C$ dans le diagnostic et la mesure de l'activité de la maladie de Crohn et de la rectocolite hémorragique. Gastroenterol Clin Biol 1979; 3: 789-94.

${ }^{10}$ Elliot PR, Lennard-Jones JE, Hathaway N. Simple index of Crohn's disease activity. Lancet 1980; $1: 876$.

${ }^{11 G r a n g e o t ~ L, ~ P i l l o t ~ J . ~ M i s e ~ e n ~ e ́ v i d e n c e ~ d ' i m m u n c o m p l e x e s ~}$ circulants chez l'homme: précipitation des immuncomplexes par le polyéthylène glycol et leur caractérisation par le Clq lié aux immunoglobulines. C R Acad Sci Paris 1975; 280: 1201-03.

${ }^{12}$ André C, Descos L, Vignal J. C reactive protein level predicts Crohn's disease relapses in quiescent patients. Gut 1979; 20: 940.

${ }^{13}$ Truelove SC, Witts LJ. Cortisone in ulcerative colitis. Final report on a therapeutic trial. Br Med J 1955; 2: 1041-48. 